\title{
PENDUGAAN RESERVOIR SISTEM PANAS BUMI DENGAN MENGGUNAKAN SURVEY GEOLISTRIK, RESISTIVITAS DAN SELF POTENSIAL (Studi Kasus: Daerah Manifestasi Panas Bumi di Desa Lombang, Kecamatan Batang-Batang, Sumenep)
}

\author{
Oleh: \\ Abdul Basid ${ }^{1}$, Nita Andrini ${ }^{2}$ dan Sofi Arfiyaningsih ${ }^{3}$
}

\begin{abstract}
ABSTRAK: Meningkatnya kebutuhan energi listrik, berkurangnya produksi dan meningkatnya harga minyak, memacu banyak negara, termasuk Indonesia untuk mengurangi ketergantungan pada pada minyak dengan cara memanfaatkan energi panas bumi. Dari hasil survey dilaporkan bahwa di Indonesia terdapat 217 prospek panasbumi, yaitu di sepanjang jalur vulkanik mulai dari bagian Barat Sumatera, terus ke Pulau Jawa, Bali, Nusatenggara dan kemudian membelok ke arah utara melalui Maluku dan Sulawesi. Jika dihitung potensi daya yang dihasilkan mencapai \pm 27.000 MWe. Daya sebesar ini membuat Indonesia merupakan Negara yang memiliki $40 \%$ potensi panas bumi dunia, tetapi baru 3\%. dari potensi panas bumi tersebut dimanfaatkan. Salah satu penelitian untuk mengetahui potensi sebaran panas bumi dilakukan di Desa Lombang Kecamatan Batang Batang Kabupaten Sumenep dengan menggunakan metode Geolistrik konfigurasi dipole-dipole dan Self Potensial (SP). Hasil penelitian dengan metode Geolistrik konfigurasi dipole-dipole menunjukkan bahwa letak air tanah berada pada kedalaman \pm 15 dan \pm 20 m di bawah permukaan tanah. Menurut teori gradient geothermal, semakin ke dalam pusat bumi, maka temperaturnya semakin tinggi pula. Demikian dengan prinsip hidrotermal yang seharusnya semakin ke bawah nilai resistivitas air semakin kecil karena konduktivitas air semakin besar. Dengan metode SP diperoleh sebaran data potensial daerah penelitian dengan nilai tertinggi mencapai $90 \mathrm{mV}$ dan terendah $-100 \mathrm{mV}$ serta rata-ratanya $0,47 \mathrm{mV}$. Berdasarkan peta kontur isopotensial yang diperoleh dapat diinterpretasi bahwa daerah penelitian merupakan zona konduktif, yang diduga berasal dari mineral sulfida dalam fluida panas. Hal ini terindikasi dengan rendahnya nilai potensial yang terukur, yang secara numerik bernilai negatif dan aliran air panas dari reservoir cenderung mengalir dari barat ke timur. Dari kajian geologi, lokasi penelitian sama sekali tidak berhubungan dengan aktivitas geologi vulkanik. Panas bumi yang ada di area penelitian diklasifikasikan panas bumi low temperature karena suhunya tidak mencapai $125{ }^{\circ} \mathrm{C}$. Panas bumi yang dihasilkan diduga disebabkan oleh adanya system geopressure.
\end{abstract}

Kata Kunci : Reservoir, Panas Bumi, Ressistivitas, Self Potensial.

\begin{abstract}
The growing need for electrical energy, reduced production and rising oil prices, spurred many countries, including Indonesia to reduce dependence on oil by utilizing geothermal energy. From the survey reported that in Indonesia there are 217 geothermal prospects, namely along the volcanic ranging from the West Sumatra, continue to the island of Java, Bali, Nusa Tenggara, and then turned to the north through the Maluku and Sulawesi. If the calculated potential generated power reaches $\pm 27,000 \mathrm{MWe}$. This makes the power of Indonesia is a country that has $40 \%$ of the world's geothermal potential, but only $3 \%$ of the geothermal potential is exploited. One study to determine the potential distribution of geothermal conducted in the village of Batang-Batang district Lombang Sumenep using Geoelectric dipole-dipole configuration and Self Potential (SP). The results of the study by the Geoelectric dipole-dipole configuration methods indicate that the location of the groundwater is at a depth of +15 and +20 m below ground level. With the SP method of data obtained distribution of potential research areas with the highest value at $90 \mathrm{mV}$ and $-100 \mathrm{mV}$ and the lowest average of $0.47 \mathrm{mV}$. Based isopotensial contour map obtained can be interpreted that the study area is a conductive zone, which is probably derived from sulfide minerals in the hot fluid. This is indicated by the low value of the measured potential, which numerically is negative and the flow of hot water from the reservoir tends to flow from west to east. From the study of geology, the study site is completely unrelated to the activity of the volcanic geology. Existing geothermal research area
\end{abstract}

1,2,3 Jurusan Fisika UIN Maulana Malik Ibrahim Malang 
classified as low temperature geothermal temperature does not reach $125^{\circ} \mathrm{C}$. Geothermal generated allegedly caused by the system geopressure.

Keyword : Reservoir, Geothermal, Ressistivitas, Self Potensial.

\section{PENDAHULUAN}

Meningkatnya kebutuhan akan energi listrik, berkurangnya produksi minyak serta meningkatnya harga minyak, memacu banyak negara, termasuk Indonesia untuk mengurangi ketergantungan pada pada minyak dengan cara memanfaatkan energi panas bumi. Saat ini energi panas bumi telah dimanfaatkan untuk pembangkit listrik di 24 Negara, termasuk Indonesia. Pencarian sumber energi panasbumi pertama kali dilakukan di daerah Kawah Kamojang pada tahun 1918. Kegiatan eksplorasi panasbumi di Indonesia baru dilakukan secara luas pada tahun 1972. Direktorat Vulkanologi dan Pertamina, dengan bantuan Pemerintah Perancis dan New Zealand melakukan survey pendahuluan di seluruh wilayah Indonesia. Dari hasil survey dilaporkan bahwa di Indonesia terdapat 217 prospek panasbumi, yaitu di sepanjang jalur vulkanik mulai dari bagian Barat Sumatera, terus ke Pulau Jawa, Bali, Nusatenggara dan kemudian membelok ke arah utara melalui Maluku dan Sulawesi.

Eksplorasi panasbumi di Indonesia dimungkikan untuk dilakukan karena Indonesia secara geografis terletak diposisi pertemuan tiga lempeng besar (Eurasia, Hindia-Australia dan Pasifik) yang menybabkan Indonesia memiliki tatanan tektonik yang kompleks. Subduksi antar lempeng benua dan samudra menghasilkan suatu proses peleburan magma dalam bentuk partial melting. Batuan mantel dan magma mengalami diferensiasi pada saat perjalanan ke permukaan. Proses tersebut membentuk kantong-kantong magma yang berperan dalam pembentukan jalur gunungapi yang dikenal sebagai lingkaran api. Munculnya rentetan gunung api Pasifik disebagaian wilayah Indonesia beserta aktivitas tektoniknya dijadikan sebagai modal konseptual pembentukan sistem panas bumi Indonesia.

Ditinjau dari sistem panas bumi, reservoar panas bumi di Indonesia ditandai dengan kemunculan gas dan mata air panas. Air panas cenderung berada di dalam batuan dengan porositas dan permeabilitas tinggi atau biasa disebut dengan zona permeabel. Nilai anomali resistivitas pada zona permeabel daerah panas bumi mempunyai karakteristik yang cenderung rendah [20]. Salah satu comtoh kemunculan air panas ini adalah ditemukannya mata air panas di daerah Lombang, Sumenep Madura yang dapat diartikan sebagai manifestasi adanya sistem panas bumi memerlukan studi lanjutan untuk melihat situasi ini sehingga kedepannya dapat dimanfaatkan sebagaimana mestinya bila benar-benar terbukti berpotensi.

Penelitian dengan metode geolistrik telah dilakukan oleh Arifin 2012 dan memberikan informasi distribusi fluida panas bumi (hydrothermal) yang merata di sekitar sumber air panas Desa Lombang. Hasil penelitian juga memperkirakan bahwa sistem panas bumi di daerah panas bumi Lombang ini berupa sistem panas bumi oleh cekungan sedimentasi. Untuk menindaklanjuti dan meyakinkan hasil tersebut, dilakukan penelitian dengan menggunakan dua metode, yaitu metode geolistrik dengan konfigurasi dipoledipole dan metode Potensial Diri (Self Potential). 
Metode geolistrik dengan konfigurasi dipole-dipole telah digunakan secara oleh para ahli geofisika Rusia sejak 1950, dan khususnya di Kanada pada eksplorasi mineral dan di Amerika untuk survey Air tanah. Metode geolistrik resistivitas konfigurasi dipole-dipole diterapkan dengan tujuan untuk mendapatkan gambaran bawah permukaan pada obyek yang penetrasinya relatif lebih dalam dibandingkan dengan metode sounding lainnya seperti konfigurasi wenner dan konfigurasi schlumberger. Metode ini sering digunakan dalam survey-survei resistivitas karena rendahnya efek elektromagnetik yang ditimbulkan antara sirkuit arus dan potensial [10].

Penerapan metode Potensial Diri (Self Potential) atau yang disingkat dengan SP ini dimungkikan untuk eksplorasi panas bumi atau geotermal karena aktivitas geotermal di bawah permukaan menyebabkan adanya kontras nilai SP yang besar (anomali) yang disebabkan adanya mekanisme thermoelektrik pada proses perambatan panas dari bawah menuju permukaan yang mengubah potensial diri struktur batuan yang dilewatinya. Adanya kontras nilai potensial diri menandakan keberadaan prospek panas bumi di bawah permukaan. Geolistrik potensial diri termasuk pengambilan data yang bersifat pasif karena untuk mendapatkan informasi bawah permukaan tanah melalui pengukuran tanpa menginjeksi arus listrik melalui permukaan tanah tersebut.

Metode SP ini sering digunakan juga pada survei hidrotermal dan digunakan untuk membantu pada proses pemetaan geologi, misalnya melihat patahan dekat permukaan dan anomali dibawah permukaan tanah. Mengetahui sumber yang dapat menyebabkan terjadinya perbedaan potensial sangat penting untuk mengurangi noise. Pengolahan data biasanya dilakukan dengan membuat peta potensial dengan antara elektroda base dengan elektroda rover. Metode SP ini sangatlah sederhana dan murah, namun metode ini hanya bekerja dengan baik untuk eksplorasi bawah permukaan dangkal yang kurang dari 100 meter. Jika kedalaman lapisan yang diinginkan melebihi 100 meter, maka sudah tidak akurat.

Pulau Madura merupakan daerah yang berpotensi memiliki banyak sumber panas bumi, salah satunya adalah Kabupaten Sumenep. Adapun lokasi-lokasi air panas bumi yang telah ditemukan di Kabupaten Sumenep antara lain adalah daerah potensi panas bumi Tirtosari; 12,5 MW. Daerah-daerah yang berpotensi memiliki sumber panas bumi tersebut memungkinkan untuk dapat dimanfaatkan dalam pemenuhan kebutuhan energi di masa mendatang khususnya sebagai sumber energi listrik untuk kepentingan lokal yang memang masih banyak belum terjangkau aliran listrik. Daerah panas bumi pada penelitian ini terletak di desa Lombang, Kecamatan Batang-Batang Kabupaten Sumenep. Berdasarkan latar belakang sebagaimana dikemukakan di atas, maka tujuan adalah mengetahui pola sebaran mata air panas bawah permukaan daerah sumber air panas Lombang Kabupaten Sumenep dengan penerapan metode geolistrik konfigurasi dipole-dipole dan Potensial Diri. Adapun area penelitian ini adalah di sekitar sumber air panas di desa LombangKecamatan Batang-Batang Kabupaten Sumenep dengan area cakupan penelitian terletak pada koordinat $6^{\circ} 55^{\prime} 48,97^{\prime}-6^{\circ} 55^{\prime} 52,79^{\prime}$ 'LS dan $113^{\circ} 04^{\prime} 05,65^{\prime}$ - $114^{\circ} 04^{\prime} 11,05^{\prime}$ ' BT.

\section{Panas Bumi (Geothermal)}

Panas Bumi atau yang dikenal dengan istilah geothermal, berasal daribahasa latin dan terbentuk dari akar kata 'geo' yang berarti bumi dan 'thermal' yang berarti panas. 
Geothermal juga dapat diartikan sebagai panas bumi yang terbentuk secara alami di bawah permukaan bumi.[1, 2013]. Panas bumi secara umum dapat diartikan sebagai jumlah kandungan panas yang tersimpan dalam bumi dan membentuk sistem panas bumi yang telah ada sejak bumi terbentuk. Sistem panas bumi tersebut mencakup sistem hidrotermal yang merupakan sistem tata air, proses pemanasan dan kondisi sistem dimana air yang terpanasi terkumpul sehingga sistem panas bumi mempunyai persyaratan seperti harus tersedianya air, batuan pemanas, batuan sarang, dan batuan penutup [2].

Sumberdaya panasbumi pada umumnya berkaitan dengan mekanisme pembentukan magma dan kegiatan vulkanisme. Sistem panas bumi dengan suhu yang tinggi, umumnya terletak di sepanjang zona vulkanik punggungan pemekaran benua, di atas zona subduksi seperti di Indonesia, dan anomali pelelehan di dalam lempeng. Batas-batas pertemuan lempeng yang bergerak merupakan pusat lokasi untuk munculnya sistem hidrotermal magma. Transfer energi panas secara konduktif pada lingkungan tektonik lempeng diperbesar oleh gerakan magma dan sirkulasi hidrotermal [8]. Adapun persyaratan utama untuk pembentukan sistem panas bumi (hidrotermal) adalah sumber panas yang besar (heat source), reservoir untuk mengakumulasi panas, dan lapisan penudung terakumulasinya panas (cap rock). Dalam system hidrotermal ini, panas dapat berpindah secara konduksi dan konveksi [8].

Sumber panasbumi (geothermal energy) dapat ditemui dibanyak tempat dimuka bumi ini. Namun daerah panasbumi yang memiliki temperatur tinggi sehingga dapat dimanfaatkan untuk pembangkit listrik tidak tersedia dibanyak tempat. Ada beberapa jenis reservoir panas bumi, yaitu reservoir hidrothermal (hydrothermal reservoir), reservoir bertekanan tinggi (geopressured reservoir), reservoir batuan panas kering (hot dry rock reservoir) dan reservoir magma [3].

Reservoir panas bumi yang paling banyak dimanfaatkan hingga saat ini adalah reservoir dari sistem hidrothermal, yaitu sistem panas bumi dimana reservoirnya mengandung uap, air atau campuran keduanya, tergantung tekanan dan temperatur reservoirnya. Apabila temperatur reservoir lebih rendah dari temperatur saturasi atau temperatur titik didih air pada tekanan reservoir tersebut, maka fluida hanya terdiri dari satu fasa saja, yaitu air. Apabila temperatur lebih tinggi dari temperatur saturasi atau temperatur titik didih air pada tekanan reservoir tersebut, maka fluida hanya terdiri satu fasa saja,yaitu uap. Pada kondisi tersebut, uap disebut sebagai superheated steam. Apabila tekanan dan temperatur reservoir sama dengan tekanan dan temperatur saturasi air maka fluida terdiri dari dua fasa, yaitu campuran uap dan air. Sistem hidrothermal yang telah ditemukan dan dimanfaatkan saat ini umumnya terletak diperbatasan lempeng tektonik. antara lain sistem hidrothermal di Italy, New Zealand, Indonesia, Phillipina, Jepang, Amerika, Mexico, El Savador dan beberapa negara lain. Sistem ini diperkirakan terbentuk karena interaksi antar lempeng tektonik yang merupakan bentangan batuan setebal 64 - 145 $\mathrm{km}$ yang mengapung di atas astenosfer. Lempeng-lempeng ini bergerak secara perlahanlahan dan menerus.

Di beberapa tempat lempeng-lempeng bergerak memisah sementara di beberapa tempat lainnya lempeng-lempeng saling mendorong dan salah satu diantaranya akan menujam di bawah lempeng lainnya (Gambar 2.1). Karena panas di dalam astenosfere dan panas akibat gesekan, ujung dari lempengan tersebut hancur meleleh, mempunyai 
temperatur tinggi (proses magmatisasi). Adanya batuan panas ini menyebabkan gradien temperatur di daerah tersebut menjadi lebih besar dari gradien temperatur rata-rata, sehingga dapat mencapai $70-800{ }^{\circ} \mathrm{C} / \mathrm{km}$, bahkan di suatu tempat besarnya gradien temperatur sangat tinggi sekali hingga besarnya tidak lagi dinyatakan dalam ${ }^{\circ} \mathrm{C} / \mathrm{km}$ tetapi dalam ${ }^{\circ} \mathrm{C} / \mathrm{cm}$.

Fluida panas bumi yang terkandung dalam reservoir hidrothermal berasal dari air permukaan, antara lain air hujan (air meteorik) yang meresap masuk ke bawah permukaan dan terpanaskan oleh suatu sumber panas (Gambar 2.1). Air tersebut akan masuk melalui rekahan-rekahan kedalam batuan permeabel. Apabila disekitar batuan tersebut terdapat sumber panas, maka panas akan dirambatkan melalui batuan (secara konduksi) dan melalui fluida (secara konveksi) [9].

Perpindahan panas secara konveksi pada dasarnya terjadi karena gaya apung. Air karena gaya gravitasi selalu mempunyai kecenderungan untuk bergerak kebawah, akan tetapi apabila air tersebut kontak dengan suatu sumber panas maka akan terjadi perpindahan panas sehingga temperatur air menjadi lebih tinggi dan air menjadi lebih ringan. Keadaan ini menyebabkan air yang lebih panas bergerak ke atas dan air yang lebih dingin bergerak turun ke bawah, sehingga terjadi sirkulasi air atau arus konveksi.

Batuan pada sistem hidrothermal umumnya merupakan batuan rekah alam. Apabila struktur geologi memungkinkan maka air tersebut akan mengalir melalui rekahan-rekahan dan atau batuan permeabel, dan kemudian muncul di permukaan. Perubahan fasa mungkin saja terjadi dalam perjalanannya ke permukaan, yaitu pada saat temperatur air telah mencapai temperatur saturasinya atau temperatur titik didihnya. Bila hal itu terjadi maka fluida akan berupa campuran uap-air atau mungkin berupa uap satu fasa saja. Hal ini menyebabkan jenis-jenis manifetasi panas bumi permukaan (geothermal surface manifestation) menjadi sangat beragam, ada mata air panas, geyser atau mata air panas yang menyembur ke permukaan hingga ketinggian mulai dari satu meter hingga beberapa puluh meter setiap selang waktu mulai dari beberapa menit hingga beberapa jam atau beberapa hari, kolam lumpur panas (mud pools), kolam air panas, serta manifestasi panasbumi lainnya yang masing-masing mempunyai karakteristik yang berbeda walaupun letaknya berdekatan.

Keanekaragaman sifat batuan dan intensitas panas menyebabkan sistem panas bumi mempunyai karakateristik yang unik, yaitu berbeda satu dengan lainnya, tidak hanya jenisjenis manifestasi permukaan dan karakteristik reservoirnya, tetapi juga dari kandungan kimia dalam air dan gas. Air meteorik (permukaan) yang masuk ke bawah permukaan melalui daerah resapan, karena terpanaskan oleh sumber panas dapat berubah komposisinya. Disamping itu batuan yang terpanaskan tentunya akan mengalami perubahan bila ada mineral batuan yang ikut larut bersama air yang melaluinya. Selain itu air panas dalam perjalanannya ke permukaan juga dapat mengalami perubahan fasa sehingga menjadi fluida dua fasa, yaitu campuran uap air. Fluida panas tersebut dapat juga bercampur dengan fluida lainnya, misalnya dengan fluida magmatik (termasuk gas-gas yang berasal dari magma) dan air dingin dari sumber lain. Komposisi fluida panas juga akan berubah akibat oksidasi di dekat permukaan [9].

Dilihat dari konsentrasi ion yang terkandung didalam air, para ahli membedakan air panas bumi menjadi empat, yaitu air Alkali Klorida, air Asam Sulfat, air Asam Sulfat- 
Klorida dan air Bikarbonat. Air Alkali Klorida dicirikan oleh kandungan Chlorida yang tinggi, kandungan $\mathrm{Na}$ dan $\mathrm{K}$ juga tinggi, kandungan $\mathrm{SiO}_{2}$ cukup tinggi (tergantung temperatur) dan $\mathrm{pH}$ sekitar $6-7$ [12].

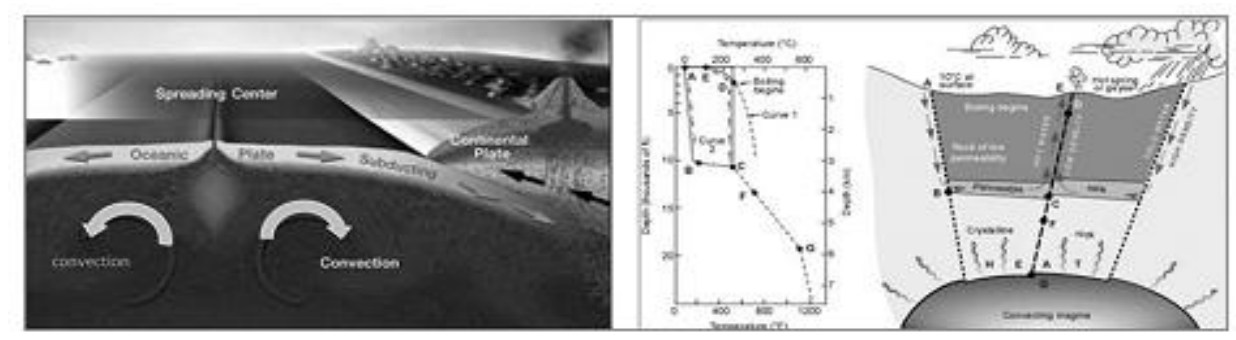

Gambar 1. Proses Pergerakan Lempeng Tektonik (Gambar dari Geothermal Education Office) dan Model Sistim Hidrothermal dari White (1967).

Sumber panas adalah intrusi batuan beku, diperkirakan terdapat pada kedalaman 2 - 5 km. Komposisi intrusi bisa granit atau gabro, tapi yang umum adalah diorit. Host rocks umumnya batuan volkanik. Temperatur reservoir tergantung dari intensitas panas yang merambat dari batuan sumber panas. Sifat termal batuan seperti kemampuan batuan merambatkan panas dan menyimpan panas (konduktivitas dan kapasitas panas batuan), kemampuan batuan mengalirkan fluida (permeabilitas batuan). Karena keanekaragaman sifat batuan, tentunya temperatur dari satu tempat ke tempat lain tidak sama, unik, dalam satu reservoir temperatur tidak homogen dan juga berbeda antara satu reservoir dengan reservoir lainnya [9].

White et al. (1971) memperkirakan dibawah reservoir dominasi uap dari air mendidih ini bergerak ke atas dan masuk kedalam reservoir dominasi uap. Uap yang ringan cenderung bergerak terus keatas. Adanya batuandengan permebilitas rendah di bagian atas reservoir menghambat aliran uap. Kondensasi terjadi karena uap kontak dengan batuan yang mempunyai temperatur lebih rendah. Kondensat karena gaya gravitasi selalu mempunyai kecenderungan untuk bergerak kebawah. Kondensat tersebut akan meningkat kembali temperaturnya setelah kontak kembali dengan sumber panas.

Pendapat lain dikemukakan oleh Grant dkk. (1982) yang mengatakan bahwa aliran uap dari boiling zone, yaitu batuan berisi air mendidih, terjadi hanya pada area atau tempat terbatas (Gambar 2). Batuan sumber panas terbatas tidak mencakup seluruh area reservoir. Dari tempat tersebut uap masuk kedalam reservoir dan mengalir secara lateral. Karena kontak dengan batuan berpemabilitas rendah, terjadi kehilangan panas karena konduksi dan terjadi kondensasi. Kondensat akan cenderung mengalir ke bawah dan selanjutnya menjadi panas kembali setelah kontak dengan sumber panas.

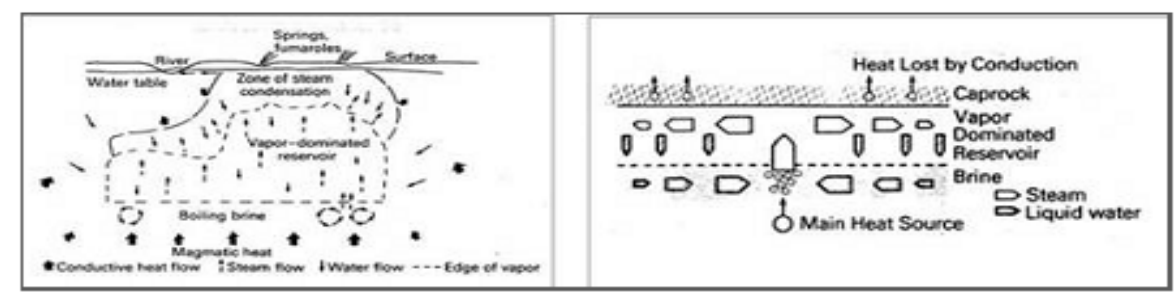

(a)

(b)

Gambar 2. (a) Model Sistim Dominasi Uap dari White (1971) dan (b) Model Sistim Dominasi D'Amor dan Truesdell (1979 dari Grant et al, 1982) 


\section{Manifestasi Panas Bumi}

Djoko Santoso (1995) mengemukakan bahwa panas bumi di permukaan bisa berbentuk seperti warm ground, steaming ground, kolam lumpur panas, kolam air panas, fumarol, sumber air panas, rembesan, geyser, dan derah alterasi hidrotermal selalu dikaitkan dengan proses geologi dan model sistem panas bumi. Warm ground adalah tanah panas. Panas yang keluar karena konduktivitas termal pada lapisan bagian atas dan gradien temperatur lebih dari $25^{\circ}-30^{\circ} \mathrm{C}$. Aliran panas yang tinggi ini dapat di deteksi dengan infra merah. Steaming ground bisa diartikan sebagai tanah beruap. Uap yang keluar berasal dari penguapan air panas pada kedalaman dangkal atau dari kedalaman yang dalam. Kolam lumpur panas atau mud vulkano adalah kubangan lumpur panas, sedikit mengandung uap dan gas $\mathrm{CO}_{2}$ dan tidak terkondensasi. Gas $\mathrm{CO}_{2}$ keluar dari satu celah dengan temperatur lebih kecil dari titik didih. Kolam air panas biasanya terdapat di tengah-tengah suatu kubahan hidrotermal minor purba dan bisa juga berbentuk hot lake. Kolam air panas terjadi dari fumarol yang sudah tidak aktif lagi. Kolam air panas yang bersistem uap air biasanya berlumpur dan berwarna abu-abu, sedang yang bersistem air panas biasanya bersih dan sedikit abu-abu, yang bersistem air panas asam terjadi pada kedalaman yang sangat dalam. Fumarol adalah hembusan gas magnetik dan uap yang keluar dengan suhu tinggi, dimana uap air umumnya lebih banyak dengan temperatur kurang dari $100^{\circ} \mathrm{C}$.

Sumber air panas biasanya berasosiasi dengan sumber air bawah permukaan yang memiliki kecepatan aliran yang tinggi, umumnya berwarna bening dengan disertai endapan silica sinter. Rembesan, aliran air panas dari kedalaman yang dalam menuju ke permukaan sebagian akan merembes ke daerah yang bertopografi rendah, hingga bercampur dengan aliran sungai. Geyser adalah sistem air panas yang memancar ke udara setiap waktu yang diakibatkan karena rongga dalam batuan terisi penuh maka tekanan akan mengakibatkan air panas atau uap terdorong keluar ke udara. Daerah alterasi hidrotermal merupakan daerah dimana antara fluida dan batuan reservoir saling bereaksi mengakibatkan perubahan fasa padat dan cair dan menghasilkan mineral baru. Kelimpahan mineral hidrotermal yang terbentuk selama interaksi fluida dan batuan tergantung pada beberapa faktor khususnya temperatur, komposisi fluida $(\mathrm{PH})$, ketersediaan fluida (permeabilitas) dan adanya pendidihan.

\section{Potensi Reservoir Panas Bumi di Indonesia}

Sebagaimana dikemukakan pada pendahuluan bahwa Kepulauan Indonesia yang terletak dipertemuan 3 lempeng besar dunia yaitu lempeng Eurasia, lempeng IndoAustralia, dan lempeng Pasifik menjadikan Indonesia sebagai salah satu Negara yang memiliki kandungan panas bumi yang sangat besar. Berdasarkan penelitian yang dilakukan oleh New Zealand dan Prancis pada tahun 1980-1990an, ditemukan 217 daerah prospek untuk lokasi panas bumi (Gambar 3). Ketika dilakukan survey ulang oleh Badan Geologi dan Direktorat Energi dan Sumber Daya Mineral, ditemukan 256 lokasi potensi panas bumi di seluruh Indonesia. Dari 256 area prospek panas bumi di Indonesia tersebut meliputi 84 area di Pulau Sumatera, 76 area di Pulau Jawa, 51 area di Pulau Sulawesi, 21 area di Nusa Tenggara, 3 area di Irian Jaya, 15 prospek di Maluku dan 5 prospek di Kalimantan. 


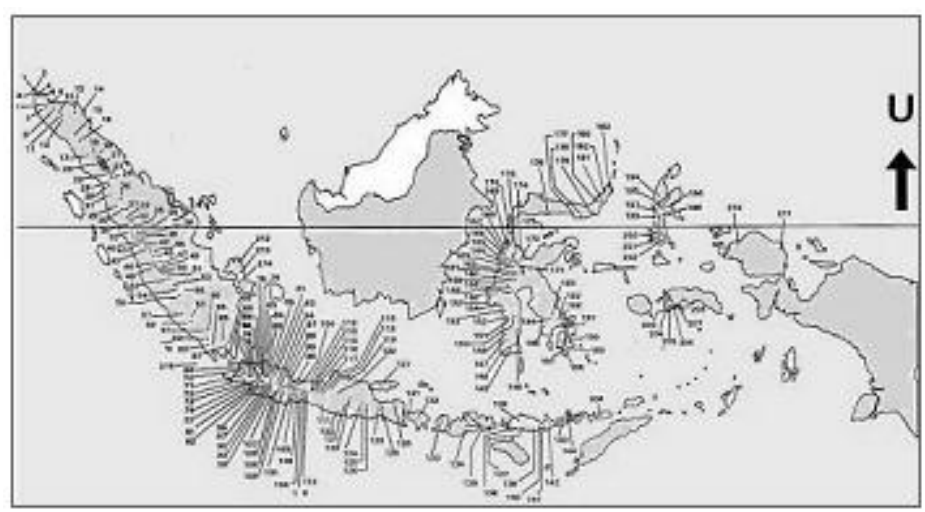

Gambar 3. Penyebaran Panas Bumi di Indonesia (Sumber DESDM)

Sistem panas bumi di Indonesia umumnya sistem hidrothermal yang mempunyai temperatur tinggi $\left(>225^{\circ} \mathrm{C}\right)$, hanya beberapa diantaranya yang mempunyai temperatur sedang $\left(125-225^{\circ} \mathrm{C}\right)$. sehingga sangat potensial apabila diusahakan untuk pembangkit listrik. Jika dihitung maka potensi daya yang dihasilkan oleh panas bumi mencapai \pm 27.000 MWe. Daya sebesar ini merupakan potensi panas bumi terbesar yang dimiliki oleh suatu negara, dan ini membuat Indonesia merupakan Negara yang memiliki $40 \%$ potensi panas bumi dunia. Dari $40 \%$ potensi panas bumi yang dimiliki, pada sekarang ini baru memamfaatkan 3\%. dari potensi panas bumi tersebut.

Dari data PLN tahun 2014 beban puncak yang pernah dicapai PLN sekitar 23.420 MW, pasokan energi yang memamfaatkan geothermal masih sangat kecil sekali dimana kapasitas daya yang dihasilkan baru 360 MW. Jika 27.000 MW potensi panas bumi yang terdapat di Indonesia dapat diproduksi maka akan dapat menutupi produksi energi listrik yang dibangkitkan oleh sumber energi lain. Dengan kata lain Indonesia akan terhindar dari krisis energi. Selain hal itu penurunan emisi gas rumah kaca di udarapun akan dapat ditekan dan lingkungan menjadi lebih bersih. Argumen lain yang dapat dikemukakan dari pentingnya pemanfaatan panas bumi ini adalah bahwa energi panas bumi salah satu energi yang berkelanjutan (renewable) dan ramah lingkungan. Panas bumi juga dapat dimamfaatkan secara langsung diantaranya adalah untuk pariwisata, misalnya untuk pemandian air panas dal lain sebagainya.

\section{Metode Geolistrik}

Metode Geolistrik merupakan salah satu metode geofisika yang digunakan dalam eksplorasi dangkal. Metode ini dilakukan dengan mengukur tahanan jenis material yang ada di dalam permukaan bumi. Tahanan jenis atau disebut dengan resistivitas merupakan besaran yang digunakan untuk mengukur tingkat hambatan material terhadap kuat arus listrik. Nilai resistivitas ini berbanding terbalik dengan konduktivitas listrik. Metode Geolistrik dilakukan dengan menginjeksikan arus listrik ke dalam tanah kemudian mengukur besaran tegangan dan kuat arus yang digunakan untuk menghitung resistivitasnya.

Konfigurasi dipole-dipole menggunakan empat buah elektroda yang terdiri dari dua elektroda potensial dan dua elektroda arus. Elektroda arus ditempatkan di urutan pertama kemudian dilanjutkan dengan elektroda potensial. Jarak AB dan MN sebesar $a$ sedangkan elektroda arus dan elektroda potensial dipisahkan oleh jarak na dimana $n$ merupakan faktor 
kali pemindahan elektroda potensial. Dengan susunan konfigurasi tersebut maka didapatkan nilai faktor geometris sebesar $\operatorname{\pi an}(n+1)(n+2)$, dan resistivitas semu:

$$
\rho=\operatorname{\pi an}(n+1)(n+2) \frac{V}{I}
$$

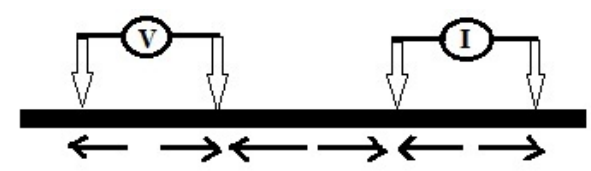

Gambar 4. Konfigurasi Dipole-dipole

\section{Metode Self Potential (SP)}

Metode potensial diri (SP) merupakan salah satu metode geofisika yang prinsip kerjanya adalah mengukur tegangan statis alam (static natural voltage) yang berada di kelompok titik-titik di permukaan tanah [19]. Potensial diri umumnya berhubungan dengan perlapisan tubuh mineral sulfida (weathering of sulphide mineral body), perubahan dalam sifat-sifat batuan (kandungan mineral) pada daerah kontak - kontak geologi, aktifitas bioelektrik dari material organik, korosi, perbedaan suhu dan tekanan dalam fluida di bawah permukaan dan fenomena-fenomena alam lainnya [21].

Self potential ini berhubungan dengan lapisan mineral yang mengandung sulfide, sifat batuan pada daerah kontak-kontak geologi, aktifitas bioelektrik material organik, korosi, dan fenomena yang lainnnya. Daerah sulfida merupakan penghantar yang baik untuk dapat membawa elektron dari kedalaman tertentu ke daerah dekat permukaan. Self potential ini dapat muncul karena adanya aktifitas elektrokimia dan mekanik di dalam bumi. Faktor pengontrol dari aktifitas tersebut adalah air tanah (ground water).

Dalam akuisisi data self potential di lapangan dapat dengan menggunakan dua cara. Cara yang pertama adalah metode gradien potensial dan yang kedua adalah metode amplitudo potensial. Untuk metode gradien potensial adalah dengan menggunakan dua buah elektroda yang dipindah dengan jarak yang tetap, dengan titik pengamatannya adalah titik lengan diantara dua elektroda tersebut. Metode amplitudo potensial juga dengan menggunakan dua buah elektroda. Elektroda petama dibiarkan tetap diluar daerah perhitungan sedangkan untukelektroda kedua dipindah sepanjang garis acuan pada jarak tetap yang kemudian diukur beda potensialnya.

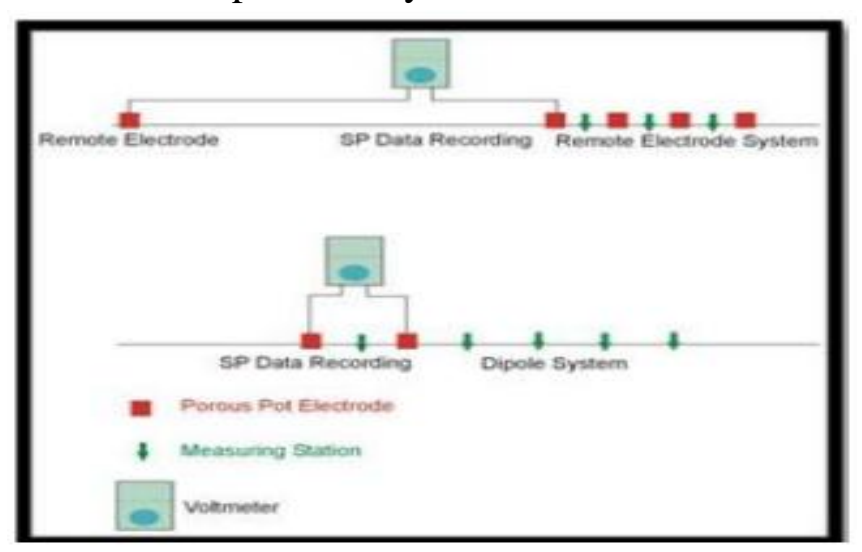

Gambar 5. Amplitudo Potensial (atas) dan Gradien Potensial (bawah) 


\section{Deskripsi Daerah Penelitian}

Daerah penelitian ini terletak di sekitar area sumber mata air panas (hydrothermal) yang berada di desa Lombang, Kecamatan Batang-batang Kabupaten Sumenep, sekitar $\pm 20 \mathrm{Km}$ dari Kota Sumenep. Secara geografis daerah penelitian terletak pada koordinat $48^{\circ} 55^{\prime} 48.97^{\prime}$ - $70^{\circ} 55^{\prime} 52.79$ " LS dan $113^{\circ} 04^{\prime} 05.65^{\prime}$ - $114^{\circ} 04^{\prime} 11.05^{\prime \prime}$ BT. Wilayah ini berada di bagian ujung timur utara dari pulau Madura atau Kabupaten Sumenep dan berhadapan dengan laut Jawa di sebelah utara sehingga daerah ini secara geografis terletak berdekatan dengan kawasan pesisir pantai utara Madura, berjarak \pm $1 \mathrm{Km}$ dari pesisir pantai.

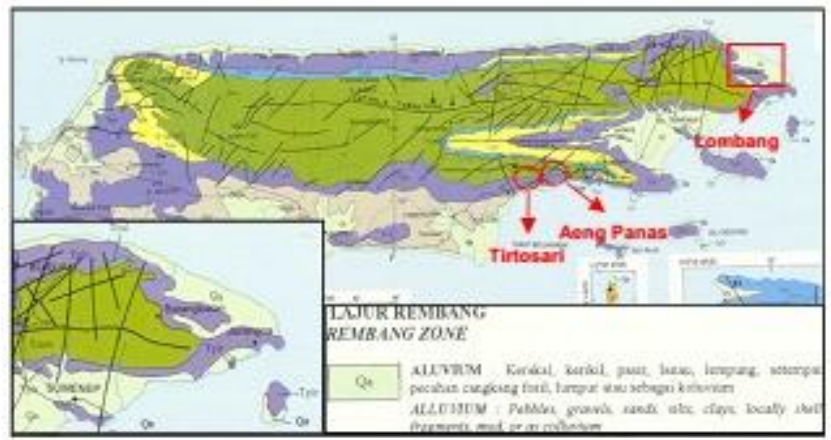

Gambar 6. Lembar geologi daerah penelitian [4]

Daerah prospek geotermal ini terletak di Kecamatan Batang-Batang, Kabupaten Sumenep, Jawa Timur (Madura). Keberadaan potensi panas bumi atau geotermal diindikasikan oleh munculnya sumber mata air panas (hot springs) di desa Lombang. Seperti halnya daerah prospek geotermal Tirtosari Sumenep, tatanan geologi (geological setting) di daerah ini didominasi oleh batuan sedimen dari Formasi Madura dan Formasi Ngrayong yang mana terdiri dari batu gampingterumbu, batu gamping dolomitedan pasir (sandstone) [22]. Prospek geotermal di desa Lombang ini diperkirakan merupakan sistem panas bumi geopressured (geopressured system) yang terasosiasi dengan depresi zona cekungan sedimen yang memanjang dari Jawa Barat ke Jawa Timur, yaitu: Bogor- Serayu Utara - Kendeng - Zona depresi selat Madura [22].

Penelitian eksplorasi dangkal untuk pendugaan adanya sebaran sumber air panas dengan aplikasi geolistrik konfigurasi dipole-dipole dan Self Potentian ini dilakukan di kawasan mata air panas Desa Lombang, Kecamatan Batang-Batang, Kabupaten Sumenep Madura. Provinsi Jawa Timur. Adapun analisis data di lakukan di Laboratorium Geofisika Jurusan Fisika Fakultas Sains dan Teknologi UIN Maulana Malik Ibrahim Malang.

Pengolahan data Geolistrik konfigurasi dipole-dipole dilakukan dengan perhitungan manual melalui software Microsoft Excel untuk mengetahui nilai resistansi (R) dan nilai resistivitas semunya ( $\rho$ a). Selanjutnya dengan menggunakan software Res2dinv untuk menampilkan pemodelan 2 Dimensi. Untuk metode SP Pengukuran data pada penelitian ini dilakukan dengan menggunakan digital milivoltmeter yang memiliki impedansi masukan tinggi untuk mengabaikan arus dari bumi selama proses pengukuran. Pada penelitian metode Potensial Diri (Self Potential)ini yaitu dengan memanfaatkan empat elektroda, dimana dua elektroda dihubungkan dengan milivoltmeter melalui kabel sebagai base (elektroda tetap), dan elektroda lainnya dihubungkan dengan milivoltmeter sebagai rover (elektroda bergerak). Rover dipindah ke titik-titik pengukuran secara berurutan 
sepanjang lintasan yang telah ditentukan dengan jarak perpindahan elektroda konstan, sehingga panjang lintasan akan mempengaruhi besarnya nilai rover. Data potensial ini belum menunjukkan nilai potensial diri pada titik ukur tersebut, karena ada perbedaan nilai di suatu titik ukur jika pengukuran diulang-ulang pada waktu yang berlainan. Oleh karena itu, data-data potensial hasil pengukuran harus dikoreksi, yang meliputi: koreksi pembacaan awal, koreksi harian, dan koreksi gangguan (noise). Data potensial yang telah terkoreksi diasumsikan sebagai data potensial diri benda anomali, dalam hal ini reservoir panas bumi yang menjadi target penelitian ini.

\section{HASIL DAN PEMBAHASAN}

\section{Metode Geolistrik}

Pengukuran geolistrik resistivitas dipole-dipole ini dilakukan sebanyak 3 lintasan.. masing-masing lintasan memiliki panjang lintasan sekitar 300 meter dalam pengukuran ini. Setiap kali pengukuran data yang diambil meliputi nilai tegangan (V), Kuat arus (I), Datum point (DP), elevasi dan koordinat DP. Pada penelitian ini kedalaman yang berhasil diidentifikasi mencapai 40 meter pada line 1 dan 2 sedangkan pada line 3 mencapai 60 meter. Pada penelitian sebelumnya yang dilakukan oleh Syamsul Arifin,2013 berhasil mengidentifikasi sampai kedalaman 25 meter dengan mengunakan metode geolistrik mapping wenner. Namun pada penelitian ini nilai eror yang dihasilkan lebih besar, yaitu ketiganya memiliki nilai eror lebih dari 50\%. Idealnya dalam data geolistrik bisa dikatakan bisa dipercaya mendekati keadaan sebenarnya memiliki nilai error tidak lebih dari 10\%. Hal ini bisa disebabkan oleh kekurang akuratan alat maupun software yang digunakan. Nilai resistivitas kecil menunjukkan nilai konduktivitas yang tinggi. Pada system hydrothermal (air panas) memiliki nilai konduktivitas yang tinggi disebabkan banyaknya ion-ion yang bebas bergerak.

Pada lintasan pertama menunjukkan bahwa letak air tanah pada kedalaman maksimal \pm 15 meter dibawah permukaan tanah. Sedangkan pada lintasan kedua $\pm 20 \mathrm{~m}$ di bawah permukaan tanah. Menurut teori gradient geothermal, semakin ke dalam pusat bumi, maka temperaturnya semakin tinggi pula. Demikian dengan prinsip hidrotermal yang seharusnya semakin ke bawah nilai resistivitas air semakin kecil karena konduktivitas air semakin besar.

\section{Metode Geolistrik Self Potensial}

Dalam penelitian ini, pengukuran (akuisisi) data geolistrik Self Potensial dilakukan pada area selebar 125 X 300 meter yang diharapkan telah dapat melokalisir sebaran aliran fluida (air) panas bawah permukaan. Interpretasi geologi bawah permukaan ini didasarkan pada data geologi dan berbagai informasi yang terkait dengan daerah survei ini. Berdasarkan informasi hasil survei, topografi daerah penelitian relatif sama berkisar pada ketinggian antara 16-22 m dpl dengan kadalaman air permukaan (aquifer zone) berkisar antara 5-8 meter dari permukaan. Keadaan ini menggambarkan keadaan topografi rendah, dimana lokasi daerah penelitian panas bumi ini terletak 1-3 km dari pesisir pantai. Sedangkan kondisi geologi daerah penelitian berdasarkan data geologi lembar Jawa bagian timur [4, 1999] secara umum terdiri dari batuan sedimen berumur Miosen-Awal hingga Pliosen, endapan alluvium (Qa) dan batu gamping Mio-Pliosen (Tplr) dengan batuan 
penyusun berupa lempung, pasir, lanau (silt), lumpur (mudstone), batu gamping pasiran, terumbu, napalan dan dolomit.

Berdasarkan analisa data diperlihatkan adanya adanya anomali di daerah ini. Nilai isopotensial yang terbaca pada daerah ini berkisar pada nilai $-100 \mathrm{mV}$ sampai dengan 90 $\mathrm{mV}$. Pada daerah anomali yakni daerah dengan tonjolan besar nilai potensialnya -60 sampai dengan $-40 \mathrm{mV}$. Nilai potensial yang sangat kecil mengindikasikan daerah yang konduktif. Berdasarkan peta kontur isopotensial yang telah dibuat dapat diinterpretasi bahwa daerah penelitian adalah zona konduktif.

Zona anomali potensial paling negatif ditemukan di kawasan selatan hingga barat daya daerah penelitian dengan nilai potensial diri mencapai $-90 \mathrm{mV}$. Hal ini mengindikasikan bahwa di zona tersebut kemungkinan terdapat sumber aliran fluida panas bawah permukaan yang cukup dangkal.Hasil pengukuran data SP menunjukkan bahwa pengukuran reservoir cenderung bersifat resistif yang ditunjukkan oleh nilai SP yang relative sedang ( nilai SP maksimum sekitar $100 \mathrm{mV}$ ). Pada jarak sekitar 100 meter nilai SP terukur sangat kecil dan bersifat resistif. Aliran air panas dari reservoir cenderung mengalir dari barat ke timur (arah atas menandakan arah utara).

Hasil pengukuran data SP menunjukkan bahwa pengukuran reservoir cenderung bersifat resistif yang ditunjukkan oleh nilai SP yang relative sedang ( nilai SP maksimum sekitar $100 \mathrm{mV}$ ). Pada jarak sekitar 100 meter nilai SP terukur sangat kecil dan bersifat resistif. Aliran air panas dari reservoir cenderung mengalir dari barat ke timur (arah atas menandakan arah utara). Interpretasi secara kuantitatif dipakai untuk menentukan parameter dari benda sehingga didapatkan kedalaman serta sudut polarisasi.

Keberadaan mata air panas (hot springs) di daerah hidrotermal desa Lombang merupakan indikasi kemungkinan adanya suatu sistem geotermal. Perubahan fisika batuan reservoar seperti porositas dan permeabilitas dapat terjadi karena alterasi hidrotermal, sedangkan pengaruh dari alterasi hidrotermal adalah menurunnya porositas. Ciri-ciri dan kelimpahan mineral hidrotermal yang terbentuk selama interaksi fluida dan batuan tergantung beberapa faktor, khususnya temperatur, komposisi fluida $(\mathrm{pH})$, ketersediaan fluida (zona permeabilitas) dan adanya pendidihan (boiling temperature). Identifikasi yang telah dilakukan pada daerah air panas ini meliputi suhu air panas yang terukur berkisar pada suhu $45^{\circ} \mathrm{C}$ (pada permukaan). Adapun komposisi mineral fluida (air) panas di desa Lombang berupa kandungan kimia Sulfur (S) atau belerang.

\section{KESIMPULAN}

Berdasar hasil penelitian metode geolistrik konfigurasi dipole-dipole dan potensial diri (self potential) menggunakan elektroda pot berpori untuk mendeteksi aliran fluida panas bawah permukaan di kawasan lombang batang-batang kabupaten Sumenep dapat disimpulkan bahwa Dengan metoda geolistrik konfigurasi dipole-dipole alam penelitian ini tidak ditemukannya sistem panas bumi, diperkirakan sistem ini masih jauh berada jauh di bawah permukaan. Panas yang terdapat pada sumber mata air panas bukan dari aktivitas vulkanik, melainkan disebabkan oleh tatanan geologi daerah setempat (geopressured system) yang terasosiasi dengan zona depresi atau cekungan sedimen yang memanjang dari Jawa Barat dan Berpangkal di Jawa Timur sekitar ujung daerah madura. Dengan metode SP diperoleh sebaran data potensial di daerah penelitian dengan nilai tertinggi yang diperoleh adalah $90 \mathrm{mV}$, 
nilai terendah adalah - $100 \mathrm{mV}$, dan nilai rata-rata adalah $0,47 \mathrm{mV}$. Berdasarkan peta kontur isopotensial yang diperoleh dapat diinterpretasi bahwa daerah penelitian merupakan zona konduktif, yang diduga berasal dari mineral sulfida dalam fluida panas. Hal ini terindikasi dengan rendahnya nilai potensial yang terukur, yang secara numerik bernilai negatif.

\section{DAFTAR PUSTAKA}

[1] Arifin, Syamsul. 2013. Interpretasi Geologi Bawah Permukaan Daerah Potensi Panas Bumi Lombang Sumenep Berdasarkan Pemodelanert. Skripsi

[2] Alzwar, M., Samodra,H., dan Tarigan, J.J.1987. Pengantar Dasar Ilmu Gunung api. Bandung: Penerbit Nova

[3] Edwards, L.M., Chilingar, G.V., Rieke, H.H. and Fertl, W.H., (eds). 1982. Handbook Of Geothermal Energy. Gulf. Houston. 1-21

[5] Grant, M.A., Donaldson, I.G. and Bixley, P.F. 1982. Geothermal Reservoir Engineering. Academic Press. New York, 3669 pp.

[6] Grover J. 2009. The Spontaneous Potential Log. Petrophysics MSc Course Notes.

[7] Hochstein and Browne. 2000. Surface Manifestations of Geothermal System with Volcanic Heat Sources. In Encyclopedia Of Volcanoes.

[8] Kasbani. Tipe Sistem Panas Bumi Di Indonesia Dan Estimasi Potensi Energinya. PMG-BadanGeologi. Jurnal

[9] Lawless, J.V., White, P.J., and Bogie, I.,1995. Tectonic Features Of Sumatra And New Zealand In Relation To Active And Fossil Hidrotermal Systems: A Comparison. Proceedings International Congress On Earth Science, Exploration And Mining Around Pacifi C Rim. AIMM., p. 311-1316.

[10] Loke.M.H. 1997.Electrical Imaging Surveys For Environmental And Engineering Studies, A Practical Guide to $2 D$ and $3 D$ Surveys. MindnHeight.Penang.Malaysia

[11] Maryanto, Sukir. 2012. Prospek Dan pemanfaatan Geothermal Sebagai Energy Alternatif; Disampaikan dalam kuliah tamu di UIN Maliki Malang, 17 Oktober 2012

[12] O’Sullivan M.J \& McKibbin R. 1989. Geothermal Reservoir Engineering, A Manual For Geothermal Reservoir Engineering Course At The Geothermal Institute. University of Auckland.

[13] Revil, A., Hubbard, S. 2009. Self Potential and Induced Polarization: Geophysical Tools to Map Flowpaths and monitor Contaminant Plumes, Department of Geophysics, Colorado Schools of Mines, U.S.

[14] Reynold. John M. 1997. AnIntroduction to Applied and Environmental Geophysics. John Wiley \& Sons Lt. Chicester 
[15] Sato and Money. 1960. The Electrochemical Mechanism Of Sulphida Self Potential. Geophysics. Vol.XXV, p. 226-246.

[16] Santoso, Djoko. 2002. Pengantar Geofisika. Bandung: Penerbit ITB

[17] Setiawan,Sigit. 2012. Energi Panas Bumi dalam Kerangka MP3I :Analisis TerhadapProspek, Kendala, dan Dukungan Kebijakan. Jurnal Ekonomi dan Pembangunan Vol. XX (1) Tahun 2012

[18] StandarNasional Indonesia 13-5012-1998ICS 73.020

[19] Sharma, P.V. 1997. Environmental and Engineering Geophysics. Cambridge University Press. United Kingdom

[20] Suhanto, E dan Bakrun. 2005. Penyelidikan Geolistrik Tahanan Jenis pada Daerah panasbumi Pincara Kabupaten Masamba Sulawesi Utara. Pemaparan Hasil Kegiatan Lapangan Subdit Panasbumi.

[21] Telford W.M, Geldart L.P., dan Sheriff R.E. 1990. Applied Geophysics Second Edition. New York : Cambridge University Press

[22] Utama, Andhika Putera Robi Irsamukhti, Mulkanul Hikmi, Johnedy Situmorang. 2012. Green Field Geothermal Systems in Java. Proceedings of 1st ITB Geothermal Workshop 2012 